\title{
Exceptionally Hot and Cold Summers in Europe (1951-2010)
}

\author{
Robert TWARDOSZ ${ }^{1}$ and Urszula KOSSOWSKA-CEZAK ${ }^{2}$ \\ ${ }^{1}$ Institute of Geography and Spatial Management, Jagiellonian University, \\ Kraków, Poland; e-mail: r.twardosz@uj.edu.pl \\ ${ }^{2}$ Department of Climatology, Faculty of Geography and Regional Studies, \\ Warsaw University, Warsaw, Poland
}

\begin{abstract}
The paper explores exceptional thermal conditions, an area of research that has increased in significance in the context of the changes that are being observed in climate. Specifically, the study addressed the frequency, long-term change and spatial coverage of exceptionally hot summers, and exceptionally cool summers (EHS and ECS) in Europe. The statistical criterion of plus/minus two standard deviations from the long-term average was used to identify EHS and ECS at 60 weather stations over the period 1951-2010. The study has demonstrated that EHS are characterised by greater temperature anomalies than ECS and are approximately twice as frequent. They occurred virtually everywhere within the study area, whilst ECS are concentrated in its northern part. Five EHS (1972, 2002, 2003, 2007, and 2010) and three ECS (1956, 1962 , and 1976) were large enough to be recorded by at least $10 \%$ of the stations.
\end{abstract}

Key words: cool summers, hot summers, temperature anomaly, Europe.

\section{INTRODUCTION}

According to the latest IPCC Report (IPCC 2013) the global mean surface air temperature (SAT) increased by $0.85 \mathrm{~K}$ between 1880 and 2012 . This in-

Ownership: Institute of Geophysics, Polish Academy of Sciences;

(C) 2015 Twardosz and Kossowska-Cezak. This is an open access article distributed under the Creative Commons Attribution-NonCommercial-NoDerivs license, http://creativecommons.org/licenses/by-nc-nd/3.0/. 
crease was caused by, among other things, an increased frequency, intensity and duration of heat waves (Perkins et al. 2012). The occurrence of heat waves causes non steady-state statistical air temperature distribution. Hansen et al. (2012) showed that the distribution of seasonal mean temperature anomalies has shifted toward higher temperatures and the range of anomalies has increased. The number of local record-breaking monthly temperature extremes is now on average five times larger than expected in a climate with no long-term warming (Coumou et al. 2013). Kamae et al. (2014) clarified why hot summers were becoming more frequent despite the slowdown of global warming. They claimed that the explanation of this effect could be found in decadal variabilities in the Pacific and Atlantic Oceans and in the direct influence of anthropogenic forcing. In interesting recent studies, Sillmann et al. $(2013,2014)$ showed that spatial trend patterns differed between the warm and cold extremes, whereby the warm extremes showed continuous positive trends across the globe and the cold extremes exhibited a coherent cooling pattern across the Northern Hemisphere mid-latitudes. In Europe at the turn of the 21st century, exceptionally hot months and even entire summers also occurred. Kossowska-Cezak and Twardosz (2013) report that during this period exceptionally cool summers were less frequent and did not occur at all between 2001 and 2010 in the central and eastern part of the continent. They also claim that the current climatic warming is accompanied by an increase in temperature variance, which means that the warming is not produced through a complete disappearance of exceptionally cool summers, but primarily through an increased frequency of exceptionally hot summers. This effect is particularly strong in Central Europe where the warming effect is stronger than elsewhere on the continent (Moberg et al. 2006).

The occurrence of anomalous thermal conditions is a feature of the temperate zone in Europe, the climate of which is determined by a highly variable atmospheric circulation. Hot summer weather is directly caused by stationary anticyclones, which are normally associated with the advection of tropical air. The combination of reduced cloudiness typical of high-pressure weather and the long summer days produces long sunshine duration. The root causes of hot summers are typically linked with the thermal conditions of the ocean (Black and Sutton 2007), especially its surface layer (DellaMarta et al. 2007, Feudale and Shukla 2011, Dole et al. 2011, Zveryaev et al. 2012), and with the increased concentration of greenhouse gases in the atmosphere (Schär et al. 2004, Stott et al. 2004, Jones et al. 2008, Gruza and Ran'kova 2011).

Cool summer spells, on the other hand, are mostly a result of any of the following: (i) advection of fresh maritime air from the Atlantic Ocean, often accompanied by intensive rainfall; (ii) northern advection (Kuziemska 1975, 
Kossowska-Cezak 1997, Jaagus 2006, Sidorenkov and Orlov 2008, Anisimov et al. 2011, Twardosz et al. 2011); or (iii) the cool advection involved in so-called "diving" Scandinavian cyclones (Elizbarashvili et al. 2007, Isayev and Sherstyukov 2008). The literature also mentions an effect of volcanic eruptions on cool summers, such as an anomalously low temperature in Europe in the summer of 1816 after the eruption of Tambora in 1815 (Piervitali et al. 1997, Trigo et al. 2009). Climatologists have given particular attention to long periods with very high temperatures, such as heat waves (Stott et al. 2004, Chase et al. 2006, Hutter et al. 2007, Kyselý and Huth 2008, Révész 2008, Founda and Giannakopoulos 2009, Rebetez et al. 2009, Kossowska-Cezak 2010, Kyselý 2010, Barriopedro et al. 2011, Dole et al. 2011, Krzyżewska and Wereski 2011, Twardosz 2009, Friedrich and Bissolli 2012, Twardosz and Batko 2012, Unal et al. 2013) or anomalously hot months and summers (Gerstengarbe and Werner 1992, Piervitali et al. 1997, Filipiuk and Kaszewski 2000, Luterbacher et al. 2004, Elizbarashvili et al. 2007, Kossowska-Cezak and Twardosz 2012a, b, Twardosz and KossowskaCezak 2013a,b,c, Wehry 2010). In view of the unfavourable biometeorological conditions, as well as droughts and wildfires, during such periods this field of research has great merit. Indeed, sustained heat stress has an exceptionally adverse influence on human health and well-being and has been demonstrated to lead to higher mortality rates (Błażejczyk and Mc Gregor 2007, Hutter et al. 2007, D'Ippoliti et al. 2010, Twardosz 2009, Muthers et al. 2010, Barriopedro et al. 2011, Zvyagintsev et al. 2011, Revich and Shaposhnikov 2012). Droughts tend to cause losses in agriculture and contribute to forest fires, sometimes over large areas, such as in the summers of 2003 and 2010 (Hodzic et al. 2007, Zvyagintsev et al. 2011).

The results of modelling research indicate that the trend to an increase in the frequency of these weather conditions may not only continue in future, but also that heat waves could become even more severe (Meehl and Tebaldi 2004, Jones et al. 2008, Révész 2008, Kürbis et al. 2009, Fischer and Schär 2010, Bardin 2011, Kamae et al. 2014, Sillmann et al. 2014). Perhaps we have already experienced a confirmation of these predictions during the events of 2003 and 2010, which have been classified as "mega-heatwaves" (Barriopedro et al. 2011).

Much less attention has been given to exceptionally cool summer months and seasons. Their effects on the economy primarily include smaller and delayed harvests of poorer quality produce, as reported in the cold and wet summer of 1816 (Trigo et al. 2009). As far as tourism is concerned, such summers affect not only the comfort of holidaymakers, but also their safety in the case of floods (de Freitas 2003, Scott and Lemieux 2010). Cool summers and summer months were particularly frequent in the 19th and early 20th century (Gerstengarbe and Werner 1992, Filipiuk and Kaszewski 2000, 
Elizbarashvili et al. 2007) and the two coolest summers in recent history were 1816 (dubbed "the year without a summer") (e.g., Piervitali et al. 1997) and 1913 (Filipiuk and Kaszewski 2000). Cool summer seasons did also occur recently, such as in 2009 in the USA (Hansen et al. 2012).

This study was designed to learn about the frequency, duration (frequency change) and spatial extent of exceptionally hot and exceptionally cool summers (EHS and ECS). The working hypothesis was that the current climatic warming has been manifested in a decreasing frequency of exceptionally cool summers and an increasing frequency of exceptionally hot summers. The study builds on the authors' earlier research (KossowskaCezak and Twardosz 2012a, b, Twardosz and Kossowska-Cezak 2013a, b, c) that focused on the central-eastern part of the continent and expands it to the entire continent of Europe. Such a comprehensive approach to thermal anomalies using Europe-wide observation data is a new contribution to a body of research that otherwise includes multiple studies on specific areas and different periods.

\section{DATA AND METHODOLOGY}

The study is based on average seasonal and monthly temperatures in summer (June to August) and on average maximum and minimum temperatures recorded at 60 stations over a 60-year period between 1951 and 2010 (Table 1). The data were obtained from the on-line European Climate Assessment \& Dataset (ECA\&D) (www.eca.knmi.nl). This database is one of four publicly available data sources (Moberg et al. 2006). It also stands out from the other such data bases, e.g., CRUTEM4 (Jones et al. 2012) and HadEX2 (Donat et al. 2013), with its superior spatial resolution and it has been used to build other data bases, e.g., HadEX2 (Donat et al. 2013). The ECA\&D data come directly from national weather services (Klein Tank et al. 2002). They have been verified for uniformity using four statistical tests (Wijngaard et al. 2003) the outcomes of which are available directly from the ECA\&D website. Some data gaps found at a small number of stations have been filled in using records from neighbouring stations processed with a generally established climatological method (quotient method).

The stations selected for the study cover the entire territory of the continent, from the Mediterranean to the northern end of the Scandinavian Peninsula and from the Atlantic Ocean to the Ural Mountains, and the British Isles. Mountain weather stations were excluded. Among the 60 stations, 35 were located at altitudes up to $100 \mathrm{~m}$ above sea level (including Astrakhan in a depression at $-23 \mathrm{~m}$ ), 17 stations at between 101 and $200 \mathrm{~m}$, and 5 stations at between 201 and $300 \mathrm{~m}$, which gives a total of 57 stations in the lowlands (Table 1, Fig. 1). Only 3 stations were located in uplands: Madrid $(667 \mathrm{~m})$, 
Table 1

Long-term average summer temperatures and the numbers of EHS and ECS in Europe (1951-2010)

\begin{tabular}{|c|c|c|c|c|c|c|c|c|c|c|c|}
\hline \multicolumn{2}{|r|}{ Station } & \multirow{2}{*}{$\begin{array}{c}\text { WMO } \\
\text { no. }\end{array}$} & \multirow{2}{*}{$\begin{array}{c}t_{\mathrm{av}} \\
{\left[{ }^{\circ} \mathrm{C}\right]}\end{array}$} & \multirow{2}{*}{ ECS } & \multirow{2}{*}{ EHS } & \multicolumn{2}{|r|}{ Station } & \multirow{2}{*}{$\begin{array}{c}\text { WMO } \\
\text { no. }\end{array}$} & \multirow{2}{*}{$\begin{array}{c}t_{\mathrm{av}} \\
{\left[{ }^{\circ} \mathrm{C}\right]}\end{array}$} & \multirow{2}{*}{ ECS } & \multirow{2}{*}{ EHS } \\
\hline No. & Name & & & & & No. & Name & & & & \\
\hline 1 & Lisbon & 8535 & 21.9 & 2 & 1 & 31 & De Bilt & 6260 & 16.5 & 1 & 1 \\
\hline 2 & Almeria & 8487 & 24.8 & 1 & 1 & 32 & Berlin & 10381 & 17.7 & - & 2 \\
\hline 3 & Crotone & & 24.8 & - & 2 & 33 & Warsaw & 12375 & 17.8 & - & 3 \\
\hline 4 & Athens & 16716 & 27.3 & 2 & 1 & 34 & Minsk & 26850 & 17.3 & - & 3 \\
\hline 5 & La Coruña & 8001 & 18.2 & 1 & 2 & 35 & Kiev & 33345 & 19.3 & - & 1 \\
\hline 6 & Madrid & 8223 & 23.4 & 1 & 1 & 36 & Kursk & 34009 & 18.4 & - & 2 \\
\hline 7 & Bordeaux & 7510 & 19.5 & - & 1 & 37 & Saratov & 31172 & 21.0 & - & 2 \\
\hline 8 & Barcelona & 8181 & 22.4 & - & 2 & 38 & Orenburg & 35121 & 20.9 & 1 & 2 \\
\hline 9 & Marseilles & 7650 & 23.0 & - & 1 & 39 & Edinburgh & 3160 & 14.1 & 1 & - \\
\hline 10 & Rome & 16235 & 23.4 & - & 2 & 40 & Oslo & 1492 & 15.8 & - & 4 \\
\hline 11 & Split & 14445 & 24.8 & 1 & 1 & 41 & Copenhagen & 6180 & 17.0 & 2 & 1 \\
\hline 12 & Belgrade & 13274 & 21.7 & - & 3 & 42 & Stockholm & 2485 & 16.5 & 1 & 1 \\
\hline 13 & Sofia & 15614 & 19.6 & 1 & 2 & 43 & Liepaja & 26406 & 16.1 & 2 & 2 \\
\hline 14 & Konstanca & 15480 & 21.8 & - & 2 & 44 & St. Petersburg & 26063 & 16.8 & 2 & 2 \\
\hline 15 & Istanbul & 17062 & 23.1 & - & 2 & 45 & Moscow & 27612 & 17.5 & 1 & 2 \\
\hline 16 & Simferopol & 33990 & 21.0 & - & 2 & 46 & Vologda & 27037 & 15.7 & - & 2 \\
\hline 17 & Sochi & 37099 & 22.2 & - & 1 & 47 & Kazan & 27595 & 18.3 & - & 2 \\
\hline 18 & Makhachkala & 37385 & 23.6 & 2 & 1 & 48 & Yekaterinburg & 28440 & 16.8 & - & 2 \\
\hline 19 & Brest & 7110 & 15.6 & 3 & 2 & 49 & Bergen & 1317 & 14.2 & - & 3 \\
\hline 20 & Paris & 7156 & 19.1 & 1 & 2 & 50 & Trondheim & 1271 & 13.5 & - & 2 \\
\hline 21 & Zurich & 6660 & 17.1 & - & 1 & 51 & Vaasa & 2911 & 14.7 & 1 & 2 \\
\hline 22 & Würzburg & 10655 & 17.9 & 1 & 1 & 52 & Kajaani & 2869 & 14.2 & 1 & 1 \\
\hline 23 & Vienna & 11035 & 19.8 & - & 2 & 53 & Arkhangelsk & 2250 & 14.1 & 2 & 2 \\
\hline 24 & Debrecen & 12882 & 20.3 & 1 & 2 & 54 & Syktyvkar & 23804 & 15.2 & 2 & 1 \\
\hline 25 & Chernivtsi & 33658 & 18.8 & 1 & 2 & 55 & Ivdel & 23921 & 15.3 & 1 & 1 \\
\hline 26 & Zaporozhe & 33805 & 21.4 & 1 & 2 & 56 & Bodo & 1152 & 12.0 & 1 & 1 \\
\hline 27 & $\begin{array}{l}\text { Rostov } \\
\text { on the Don }\end{array}$ & 34731 & 22.3 & - & 3 & 57 & Sodankyla & 2836 & 12.8 & 1 & - \\
\hline 28 & Astrakhan & 34880 & 24.1 & 1 & 1 & 58 & Naryan-Mar & 2320 & 10.7 & 1 & 1 \\
\hline 29 & Valentia & 3953 & 14.6 & 1 & 2 & 59 & Pechora & 23418 & 13.3 & - & - \\
\hline 30 & London & 3776 & 16.4 & - & 2 & 60 & Vardö & 1098 & 8.4 & - & 2 \\
\hline
\end{tabular}




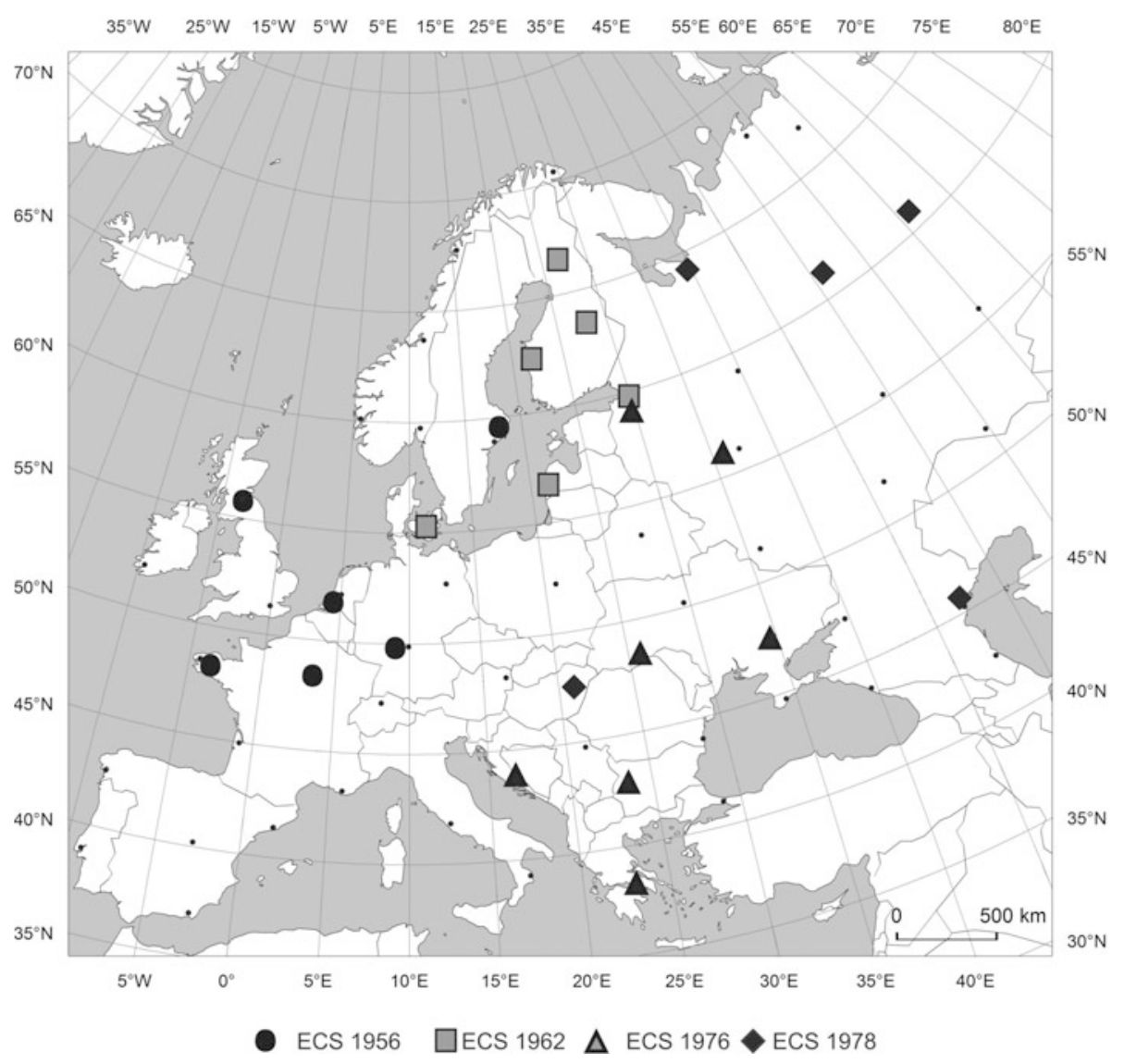

Fig. 1. Stations with ECS: 1956, 1962, 1976, and 1978.

Sofia $(595 \mathrm{~m})$, and Zurich $(569 \mathrm{~m})$. The stations were coded from 1 to 60 going from west to east in belts spanning 5 degrees of latitude, i.e., up to $40^{\circ} \mathrm{N}$ -4 stations (nos. 1 to 4 ), $40-45^{\circ} \mathrm{N}-14$ stations $(5-18), 45-50^{\circ} \mathrm{N}-10$ stations $(19-28), 50-55^{\circ} \mathrm{N}-10$ stations (29-38), $55-60^{\circ} \mathrm{N}-10$ stations (39-48), $60-$ $65^{\circ} \mathrm{N}-7$ stations $(49-55), 65-70^{\circ} \mathrm{N}-4$ stations $(56-59)$, and above $70^{\circ} \mathrm{N}-$ 1 station (no. 60) (Table 1, Fig. 1).

Summers were classified as exceptionally cool or hot when the average seasonal temperature at a given station differed from its respective 60 -year counterpart (1951-2010) by two or more standard deviations (i.e., EHS: $t \geq t_{\mathrm{av}}+2 \sigma$; ECS: $t \leq t_{\mathrm{av}}-2 \sigma$ ). The same approach was followed when identifying exceptional months. This definition is analogous to the one used when identifying exceptionally hot months and seasons in Central and Eastern Europe (Kossowska-Cezak and Twardosz 2012a, b, 2013, Twardosz and 
Kossowska-Cezak 2013a, b, c). By referencing average thermal conditions in defining thermally anomalous periods, the study managed to take into account both the concept of a thermal anomaly in the form established in climatology and the actual thermal conditions to which the populations of the various European climatic regions were acclimatised. The method also offered the benefit of obtaining information on very important characteristics of the climate, such as the scale of the anomaly and its frequency of occurrence. For this latter reason the authors decided, right from the start, not to employ the increasingly popular (and strongly popularised) percentile method which, by definition, did not offer these characteristics.

The numbers of days with the maximum temperature above $30^{\circ} \mathrm{C}$ (hot days) and with the minimum temperature above $20^{\circ} \mathrm{C}$ (tropical nights) were used to characterise the EHS and ECS identified.

The method yielded a number of exceptionally hot and cool summers, as well as calendars of their occurrence and the areas where they occurred.

\section{FREQUENCY OF EHS AND ECS}

Using the criterion of average temperature plus/minus two standard deviations, 42 ECS were identified in 13 years of the study period. ECS only occurred at 32 of the 60 stations (mostly in northern Europe), mostly only once (23 stations) with just Brest, on the western tip of the continent, recording three occurrences (Table 2).

Table 2

The number of EHS and ECS and the number of their occurrences

\begin{tabular}{|c|c|c|c|c|}
\hline \multirow{2}{*}{10 -years } & \multicolumn{2}{|c|}{ ECS } & \multicolumn{2}{c|}{ EHS } \\
\cline { 2 - 5 } & $\begin{array}{c}\text { Number } \\
\text { of years }\end{array}$ & $\begin{array}{c}\text { Number } \\
\text { of occurrences }\end{array}$ & $\begin{array}{c}\text { Number } \\
\text { of years }\end{array}$ & $\begin{array}{c}\text { Number } \\
\text { of occurrences }\end{array}$ \\
\hline $1951-1960$ & 2 & 7 & 2 & 4 \\
$1961-1970$ & 2 & 9 & - & - \\
$1971-1980$ & 5 & 20 & 3 & 12 \\
$1981-1990$ & 2 & 3 & 3 & 7 \\
$1991-2000$ & 2 & 3 & 7 & 14 \\
$2001-2010$ & - & - & 9 & 63 \\
\hline $\mathbf{1 9 5 1 - 2 0 1 0}$ & $\mathbf{1 3}$ & $\mathbf{4 2}$ & $\mathbf{2 4}$ & $\mathbf{1 0 0}$ \\
\hline
\end{tabular}

The largest number of five ECS was recorded in the decade 1971-1980 (Table 2), and during the period 1969-1978 there were six examples (Table 3). During the decade 1971-1980, 20 stations recorded an ECS (Table 2) and in the decade 1969-1978 there were 23 stations with an ECS, which ac- 
Table 3

Exceptionally cool summers (ECS) (1951-2010)

\begin{tabular}{|c|c|l|}
\hline Year & $\begin{array}{c}\text { Number } \\
\text { of stations }\end{array}$ & \multicolumn{1}{|c|}{\begin{tabular}{c}
\multicolumn{1}{|c|}{ Stations } \\
(no. according to Table 1)
\end{tabular}} \\
\hline 1954 & 1 & 19 \\
1956 & 6 & $19,20,22,31,39,(42)$ \\
1962 & 6 & $(41),(43),(44),(51),(52),(57)$ \\
1969 & 3 & $53,54,58$ \\
1972 & 3 & $1,19,29$ \\
1975 & 1 & 56 \\
1976 & 7 & $4,11,13,25,26,(44),(45)$ \\
1977 & 4 & $1,2,(5), 6$ \\
1978 & 5 & $(24), 28,(53),(54),(55)$ \\
1984 & 1 & 4 \\
1987 & 2 & $41,(43)$ \\
1993 & 1 & 18 \\
1994 & 2 & 18,38 \\
\hline
\end{tabular}

Note: station codes in parentheses denote stations without an ECM during an ECS.

counts for more than half of all station/ECS. This means that ECS not only occurred the most frequently during that period, but also that they tended to cover wider areas. There were no ECS in the last decade in the study, but the decline in their occurrence had begun much earlier: after 1978 (4 stations reporting an ECS) exceptionally cool summers would only occur at 1-2 stations and not a single occurrence has been recorded since 1995. The greatest area with an ECS was recorded in 1976 when it covered 7 stations in SouthEastern Europe and in the central part of European Russia, and that was followed by 2 years (1956 and 1962) with 6 stations each.

EHS were far more frequent and were recorded at 100 cases in 24 years of the study period (Table 2). Only stations at Edinburgh, Sodankyla, and Pechora did not record any EHS, while most stations recorded two (29 stations) or three EHS (21 stations), with Oslo standing out with four occurrences. The greatest frequency of EHS was noted during the last decade (2001-2010) with nine such seasons (including every year from 2002) recorded at 63 stations (more than $63 \%$ of all stations) (Table 2). This means that the EHS of that period were not just very frequent, but also covered extended areas. The preceding decade (1991-2000) had seven EHS, but with just 14 stations involved the seasons clearly had a smaller spatial extent. Exceptionally hot summers were not recorded at all during the decade 1961- 
1970 and in fact even during 1960-1971 (Table 4). While the period of most frequent occurrence of ECS (1971-1980) did not overlap with the period of lowest frequency (in fact lack of) EHS (1961-1970), the reverse correlation, i.e., lack of ECS and the most frequent EHS, overlapped fully towards the latter part of the study period, i.e., beginning virtually in 1995. The largest EHS included 20 stations in Eastern Europe (without its northern tip) in

Table 4

Exceptionally hot summers (EHS) (1951-2010)

\begin{tabular}{|c|c|c|}
\hline Year & $\begin{array}{l}\text { Number } \\
\text { of stations }\end{array}$ & $\begin{array}{c}\text { Stations } \\
\text { (no. according to Table 1) }\end{array}$ \\
\hline 1955 & 3 & $29,30,40$ \\
\hline 1959 & 1 & 30 \\
\hline 1972 & 9 & $27,36,37,44,45,46,52,53,60$ \\
\hline 1974 & 1 & $(53)$ \\
\hline 1976 & 2 & 19,20 \\
\hline 1981 & 3 & $(47), 48,55$ \\
\hline 1988 & 2 & 48,54 \\
\hline 1989 & 2 & 1,2 \\
\hline 1992 & 4 & $23,24,32,33$ \\
\hline 1993 & 1 & 58 \\
\hline 1995 & 1 & 29 \\
\hline 1997 & 4 & $40,49,50,51$ \\
\hline 1998 & 2 & 3, 38 \\
\hline 1999 & 1 & 34 \\
\hline 2000 & 1 & 12 \\
\hline 2002 & 8 & $34,40,42,43,49,50,51,56$ \\
\hline 2003 & 17 & $\begin{array}{l}3,4,6,7, \mathbf{8}, \mathbf{9}, \mathbf{1 0}, \mathbf{1 1}, 12,19,20, \mathbf{2 1} \\
\mathbf{2 2}, \mathbf{2 3}, 31,32,49\end{array}$ \\
\hline 2004 & 1 & 60 \\
\hline 2005 & 1 & 5 \\
\hline 2006 & 5 & $5,8,33,40,41$ \\
\hline 2007 & 9 & $12,13,14,15,16,24,(25), 26,(27)$ \\
\hline 2008 & 1 & 13 \\
\hline 2009 & 1 & 10 \\
\hline 2010 & 20 & $\begin{array}{l}14,15,16, \mathbf{1 7}, 18,25,26,27, \mathbf{2 8},(33), \\
34, \mathbf{3 5}, \mathbf{3 6}, 37, \mathbf{3 8}, 43,44, \mathbf{4 5}, 46, \mathbf{4 7}\end{array}$ \\
\hline
\end{tabular}

Notes: station codes in parentheses denote stations without an EHM during an EHS, station numbers printed in bold mean that the average temperature met the criterion $t \geq t_{\mathrm{av}}+3 \sigma$. 
2010; 16 stations in Western and Central Europe in 2003; 9 stations in 1972 (Northern and Eastern Europe), 2002 (Scandinavian Peninsula and Central Europe), and 2007 (South-Western Europe).

There were 3 years during the study period when ECS and EHS coincided. In 1972, there was an ECS in the far west of the continent (3 stations) and an EHS in Northern and Eastern Europe (9 stations). In 1976, the largest ECS of the period (7 stations) occurred in Central Europe, while an EHS occurred in Western Europe (2 stations). In 1993, an ECS over the Caspian Sea (1 station) coincided with an EHS in the far north-east (1 station).

In summary, the greater frequency of exceptionally hot than exceptionally cool summers is an obvious consequence of the properties of the summertime statistical distribution of temperature. Indeed, many authors (e.g., Piervitali et al. 1997, Luterbacher et al. 2004, Elizbarashvili et al. 2007, Kossowska-Cezak and Twardosz 2013) agree that this distribution is characterised by a right-skewed asymmetry, i.e., sporadic occurrence of temperatures considerably greater than the long-term average compensated by a greater frequency of lower discrepancies below the average.

These properties of the long-term average summer temperatures are linked with factors influencing temperature in this geographic zone. At a time of persistent high pressure systems that tend to prevent increased cloudiness, thus ensuring high insolation on long summer days, advection of hot tropical or polar continental air may lead to very high and persistent increases of air temperature. On the other hand, an influx of much cooler arctic or polar maritime air, even with increased cloudiness, does not produce as much of a negative thermal anomaly because it is offset by the solar conditions characteristic of summer. Even in subpolar areas the air remains warm due to the long day and to the influence of the Arctic Ocean.

\section{THERMAL CHARACTERISTICS OF EHS AND ECS}

The full calendar of years with EHS and ECS, including the number and code of the stations, is provided in Tables 3 and 4. As has already been noted, ECS occurred in 13 years of the study period, including 4 years at 1 station and 2 years at 2 stations (Table 3 ). These 6 years in which ECS were recorded at less than 3 stations (i.e., less than $5 \%$ of stations) were omitted in the data on thermal characteristics given in this section. This leaves 7 years when ECS covered areas with between 3 and 7 stations.

EHS were much more frequent than ECS occurring in 24 years during the study period. In a similar manner to ECS, exceptionally hot summers were also frequently recorded at just one (10 years) or two (4 years), typically neighbouring, stations in a given year (Table 4). These occurrences were also omitted in this section. The EHS in the remaining 10 years covered areas with between 3 and 20 stations. 
The characteristics of individual EHS and ECS include not just their location and approximate extent indicated by the recording stations, but also the scale of the temperature anomaly $(\Delta t)$ measured as the difference between the average temperature of the summer in question and the long-term average. Additionally, the authors noted the number of exceptionally hot or cool months, if any, during the EHS or ECS $\left(t \leq t_{\mathrm{av}}-2 \sigma\right.$ or $\left.t \geq t_{\mathrm{av}}+2 \sigma\right)$.

\subsection{Exceptionally cool summers (ECS)}

The ECS of 1956 covered part of north-western Europe (5 stations) plus Stockholm (Fig. 1). August was an exceptionally cool month. The temperature anomaly $(\Delta t)$ ranged from -1.3 to $1.7^{\circ} \mathrm{C}$ in the west and $-2.6^{\circ} \mathrm{C}$ in the east of the area (Table 5).

The ECS of 1962 encompassed eastern Scandinavia, the eastern Baltic coast (5 stations altogether) and Copenhagen (Fig. 1). It included no exceptionally cool months. The temperature anomaly $(\Delta t)$ ranged from $-2.0^{\circ} \mathrm{C}$ in Copenhagen to $-2.8^{\circ} \mathrm{C}$ in Sondankyla (Table 5).

The ECS of 1969 was noted at 3 stations in north-eastern Europe (Arkhangelsk, Syktyvkar, and Naryan-Mar). June was an exceptionally cool month. The temperature anomaly ranged from $-2.6^{\circ} \mathrm{C}$ in the west to $-3.7^{\circ} \mathrm{C}$ in the north-east.

The ECS of 1972 covered an area with 3 stations on the Atlantic coast: Lisbon $\left(\Delta t=-1.8^{\circ} \mathrm{C}\right)$, Brest $\left(\Delta t=-1.7^{\circ} \mathrm{C}\right)$, and Valentia $\left(\Delta t=-1.3^{\circ} \mathrm{C}\right)$. The anomaly at Valentia may be smallest in absolute terms, but in terms of standard deviation at it stood out at $\Delta t=t \leq t_{\mathrm{av}}-3 \sigma$. June was exceptionally cool. This ECS coincided with an EHS in Central and Eastern Europe.

Table 5

Thermal characteristic of the exceptionally cool summers (ECS)

\begin{tabular}{|c|c|c|c|c|c|c|c|c|c|}
\hline \multirow{3}{*}{ Year } & \multirow{2}{*}{\multicolumn{2}{|c|}{ Station }} & \multicolumn{5}{|c|}{ Temperature } & \multirow{2}{*}{\multicolumn{2}{|c|}{$\begin{array}{l}\text { Number of days } \\
\text { with temperature }\end{array}$}} \\
\hline & & & \multirow{2}{*}{$\begin{array}{l}T_{\mathrm{av}} \\
{ }^{\circ} \mathrm{C}\end{array}$} & \multicolumn{2}{|c|}{$\Delta t$} & \multirow{2}{*}{$\frac{T_{\max }}{{ }^{\circ} \mathrm{C}}$} & \multirow{2}{*}{$\frac{T_{\min }}{{ }^{\circ} \mathrm{C}}$} & & \\
\hline & No. & Name & & ${ }^{\circ} \mathrm{C}$ & $\sigma$ & & & $T_{\max }>30^{\circ} \mathrm{C}$ & $T_{\min }>20^{\circ} \mathrm{C}$ \\
\hline \multirow{2}{*}{1956} & 20 & Paris & 16.5 & -2.6 & 2.2 & 20.8 & 12.2 & 3 & - \\
\hline & 22 & Würzburg & 15.7 & -2.2 & 2.0 & 20.4 & 11.5 & - & - \\
\hline \multirow{2}{*}{1962} & 41 & Copenhagen & 15.0 & -2.0 & 2.0 & 18.6 & 11.2 & - & - \\
\hline & 44 & St. Petersburg & 14.2 & -2.6 & 2.2 & 18.1 & 10.7 & - & - \\
\hline \multirow{3}{*}{1976} & 4 & Athens & 25.4 & -1.9 & 2.3 & 30.9 & 20.8 & 53 & 59 \\
\hline & 44 & St. Petersburg & 14.3 & -2.5 & 2.1 & 17.9 & 11.1 & - & 1 \\
\hline & 45 & Moscow & 14.8 & -2.7 & 2.1 & 19.4 & 10.6 & - & - \\
\hline \multirow{2}{*}{1978} & 28 & Astrakhan & 21.9 & -2.2 & 2.2 & 28.1 & 16.6 & 29 & 11 \\
\hline & 53 & Arkhangelsk & 11.6 & -2.5 & 2.0 & 16.8 & 7.4 & 1 & - \\
\hline
\end{tabular}


The ECS of 1976 covered the largest area in the study period and included 7 stations from Athens in the south across the Balkan Peninsula to southern Ukraine, Moscow, and St. Petersburg (Fig. 1). August was exceptionally cool over the whole area, while Sofia also had an exceptionally cool June and Zaporozhe also had an exceptionally cool July. The temperature anomaly ranged from -2.0 to $-3.0^{\circ} \mathrm{C}$ (Table 5). In the same year, an EHS was recorded in Brest and Paris.

The ECS of 1977 was recorded by stations on the Iberian Peninsula (4 stations). All stations recorded at least one exceptionally cool month, but in Almeria it was all three (June-August), and in Madrid, June, and August. The temperature anomaly reached between -1.6 and $-1.9^{\circ} \mathrm{C}$, but in Madrid up to $-3.5^{\circ} \mathrm{C}$.

A total of 5 stations in three different areas recorded the ECS of 1978: in the north-east (Arkhangelsk, Syktyvkar, Ivdel; there were no exceptionally cool months, $\Delta t$ ranged from -2.5 to $-3.0^{\circ} \mathrm{C}$ ); in Astrakhan (exceptionally cool June, $\Delta t=-2.5^{\circ} \mathrm{C}$ ); and at Debrecen (no exceptionally cool months, $\Delta t=-2.1^{\circ} \mathrm{C}$ ) (Fig. 1).

A review of ECS covering at least $5 \%$ of the weather stations showed that while some ECS occurred in a single area, others affected several discrete ones. Perhaps the reason for this uneven spatial distribution of the thermal anomalies is linked to the atmospheric circulation. Understanding of this influence would require access to regional catalogues of circulation types, which are not always available. The scale of thermal anomalies identified was not great and mostly did not exceed $-3.0^{\circ} \mathrm{C}$ with a maximum of $-3.5^{\circ} \mathrm{C}$ (Madrid in 1977).

\subsection{Exceptionally hot summers (EHS)}

The EHS of 1955 occurred at 3 stations in Western Europe (Table 4), including Valentia, London, and Oslo. August was exceptionally hot at all 3 stations, as also was July in Oslo. The temperature anomaly at Valentia stood at $\Delta t=1.4^{\circ} \mathrm{C}$ and elsewhere at $2.5-2.3^{\circ} \mathrm{C}$.

The EHS of 1972 covered large areas of Eastern Europe ( 9 stations) from Rostov to Kursk and Saratov to Moscow and St. Petersburg all the way to the northern tip of Scandinavia (Fig. 2). Exceptionally hot months included August (at most stations), June (Rostov), and July (Kajaani and St. Petersburg - together with August). The temperature anomaly ranged from $2.4-2.7^{\circ} \mathrm{C}$ in the north to $3.3-3.7^{\circ} \mathrm{C}$ in the centre and peaked at Saratov (Table 6).

The EHS of 1981 covered 3 stations in Eastern Europe: Kazan, Yekaterinburg, and Ivdel. The latter two recorded an exceptionally hot August. The temperature anomaly $\Delta t$ ranged from 2.7 to $3.2^{\circ} \mathrm{C}$. 


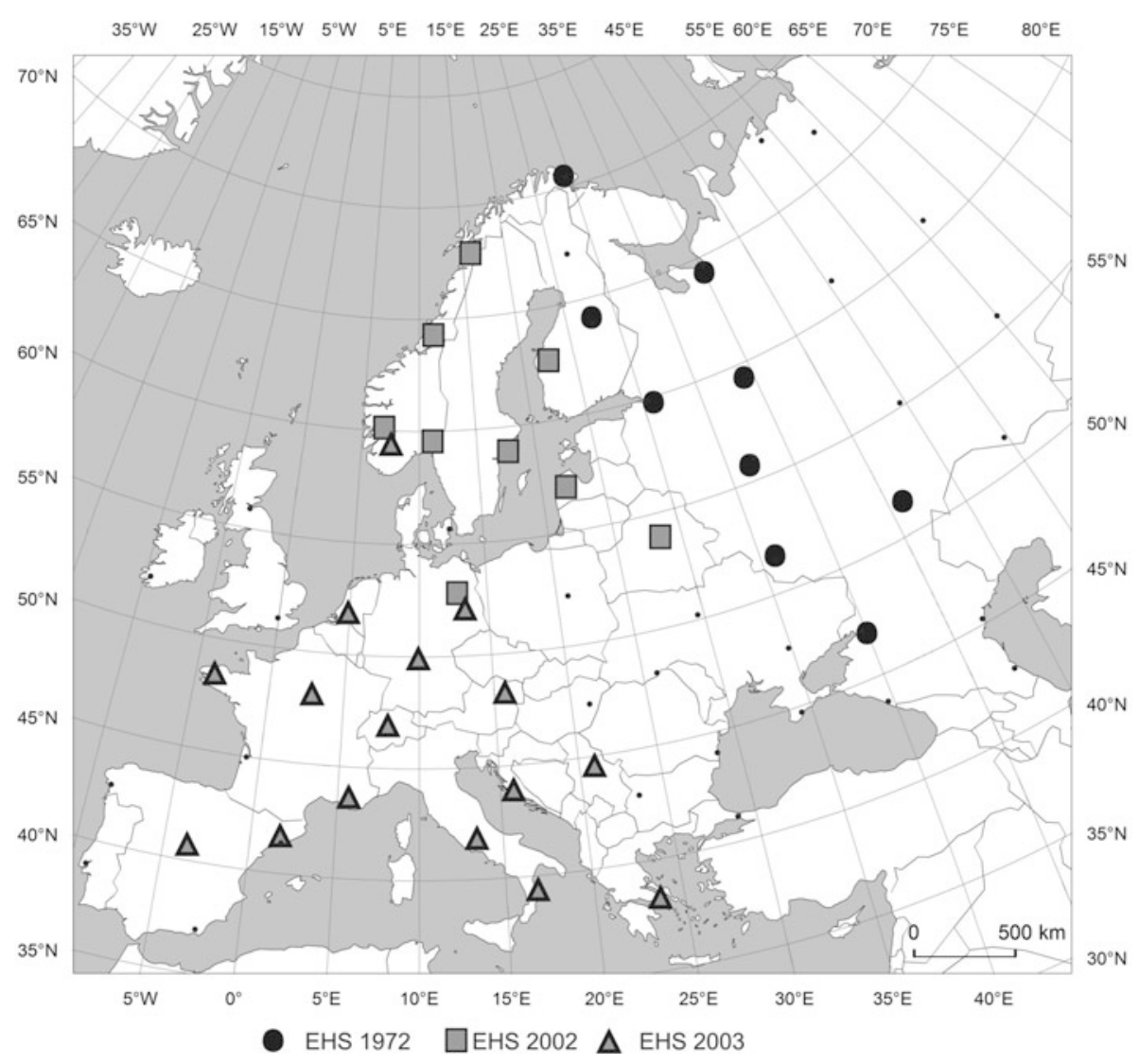

Fig. 2. Stations with EHS: 1972, 2002, and 2003.

The EHS of 1992 included 4 stations in Central Europe: Berlin, Warsaw, Vienna, and Debrecen. August was exceptionally hot (including $t \geq t_{\mathrm{av}}+3 \sigma$ at Vienna and Debrecen). The temperature anomaly $\Delta t$ ranged from 2.2 to $2.4^{\circ} \mathrm{C}$. While high, it did not constitute the highest summer temperature anomaly of the 20th century in Central Europe. Indeed, Kossowska-Cezak (1993) and Filipiuk and Kaszewski (2000) found that the greatest anomalies were recorded in the summer of 1939. Exceptionally high temperatures in the north of Central Europe were caused by the southern advection of tropical air, which was augmented by a foehn effect across the mountain barrier of the Sudeten and Carpathian Mts. (Kuziemska 1987, Kossowska-Cezak 1993). This type of weather is linked to a wedge of the Azores' high (Fink et al. 2004).

The EHS of 1997 also involved 4 stations, but this time in central Scandinavia, including: Oslo, Bergen (exceptionally hot August), Trondheim, and 
Vaasa (exceptionally hot July and August). The temperature anomaly ranged from 2.5 to $2.8^{\circ} \mathrm{C}$, but peaked in Oslo at $3.9^{\circ} \mathrm{C}$.

Table 6

Thermal characteristic of the exceptionally hot summers (EHM) temperature

\begin{tabular}{|c|c|c|c|c|c|c|c|c|c|}
\hline \multirow{3}{*}{ Year } & \multirow{2}{*}{\multicolumn{2}{|c|}{ Station }} & \multicolumn{5}{|c|}{ Air temperature } & \multirow{2}{*}{\multicolumn{2}{|c|}{$\begin{array}{l}\text { Number of days } \\
\text { with temperature }\end{array}$}} \\
\hline & & & \multirow{2}{*}{$\begin{array}{l}T_{\mathrm{av}} \\
{ }^{\circ} \mathrm{C}\end{array}$} & \multicolumn{2}{|c|}{$\Delta t$} & \multirow{2}{*}{$\begin{array}{c}T_{\max } \\
{ }^{\circ} \mathrm{C}\end{array}$} & \multirow{2}{*}{$\frac{T_{\min }}{{ }^{\circ} \mathrm{C}}$} & & \\
\hline & No. & Name & & ${ }^{\circ} \mathrm{C}$ & $\sigma$ & & & $T_{\text {max }}>30^{\circ} \mathrm{C}$ & $T_{\min }>20^{\circ} \mathrm{C}$ \\
\hline \multirow[t]{5}{*}{1972} & 27 & $\begin{array}{l}\text { Rostov } \\
\text { on the Don }\end{array}$ & 25.2 & +2.9 & 2.2 & 31.8 & 19.3 & 67 & 37 \\
\hline & 36 & Kursk & 21.6 & +3.2 & 2.0 & 27.2 & 16.2 & 21 & 6 \\
\hline & 44 & St. Petersburg & 20.1 & +3.3 & 2.8 & 25.0 & 15.8 & 16 & 14 \\
\hline & 45 & Moscow & 20.7 & +3.2 & 2.4 & 26.4 & 14.7 & 24 & 6 \\
\hline & 53 & Arkhangelsk & 16.8 & +2.7 & 2.1 & 22.8 & 11.1 & 11 & 6 \\
\hline \multirow[t]{3}{*}{2002} & 42 & Stockholm & 19.3 & +2.8 & 2.2 & 24.2 & 15.4 & 2 & 1 \\
\hline & 49 & Bergen & 16.6 & +2.4 & 2.4 & 20.6 & 13.6 & - & 1 \\
\hline & 56 & Bodo & 14.7 & +2.7 & 2.4 & 18.1 & 11.6 & - & - \\
\hline \multirow[t]{7}{*}{2003} & 4 & Athens & 29.0 & +1.7 & 2.0 & 33.1 & 22.9 & 86 & 83 \\
\hline & 8 & Barcelona & 26.6 & +4.2 & 3.5 & 31.2 & 22.1 & 71 & 75 \\
\hline & 10 & Rome & 26.9 & +3.5 & 3.7 & 33.0 & 20.9 & 76 & 62 \\
\hline & 20 & Paris & 22.6 & +3.5 & 3.0 & 27.6 & 17.6 & 20 & 16 \\
\hline & 21 & Zurich & 21.7 & +4.5 & 4.2 & 27.8 & 16.3 & 25 & 2 \\
\hline & 32 & Berlin & 20.0 & +2.3 & 2.3 & 25.9 & 14.1 & 18 & - \\
\hline & 49 & Bergen & 16.2 & +2.0 & 2.0 & 20.4 & 13.0 & 2 & - \\
\hline \multirow[t]{2}{*}{2006} & 8 & Barcelona & 24.8 & +2.4 & 2.0 & 28.5 & 21.0 & 32 & 65 \\
\hline & 41 & Copenhagen & 18.9 & +1.9 & 2.0 & 23.4 & 14.8 & 2 & 2 \\
\hline \multirow[t]{2}{*}{2007} & 15 & Istanbul & 25.8 & +2.7 & 2.8 & 30.7 & 21.6 & 53 & 66 \\
\hline & 27 & $\begin{array}{l}\text { Rostov } \\
\text { on the Don }\end{array}$ & 25.4 & +3.1 & 2.4 & 32.0 & 19.0 & 63 & 35 \\
\hline \multirow[t]{7}{*}{2010} & 15 & Istanbul & 25.4 & +2.3 & 2.3 & 29.7 & 21.5 & 51 & 62 \\
\hline & 18 & Makhachkala & 26.0 & +2.5 & 2.8 & 30.2 & 21.7 & 49 & 67 \\
\hline & 27 & $\begin{array}{l}\text { Rostov } \\
\text { on the Don }\end{array}$ & 26.1 & +3.8 & 2.9 & 32.5 & 20 & 64 & 46 \\
\hline & 28 & Astrakhan & 27.5 & +3.4 & 3.4 & 34.9 & 20.4 & 84 & 55 \\
\hline & 36 & Kursk & 24.2 & +5.8 & 3.9 & 30.3 & 18.6 & 52 & 37 \\
\hline & 44 & St. Petersburg & 19.8 & +3.0 & 2.5 & 24.1 & 15.8 & 20 & 21 \\
\hline & 45 & Moscow & 22.2 & +4.7 & 3.6 & 27.8 & 16.4 & 44 & 25 \\
\hline
\end{tabular}

Note: a value in bold means that the temperature meets the criterion $t \geq t_{\mathrm{av}}+3 \sigma$. 
The EHS of 2002 covered north-central Europe from Minsk to the Baltic coast and a majority of the Scandinavian Peninsula to the town of Bodo (Fig. 2). August was exceptionally hot everywhere (including $t>t_{\mathrm{av}}+3 \sigma$ at Bergen), except in Bodo when the hot month was June. The scale of the anomaly was distributed in a rather irregular way and ranged from 2.1 to $3.3^{\circ} \mathrm{C}$.

The EHS of 2003 was the second largest in terms of territory; it included 16 stations in Western and Southern Europe (Fig. 2). Its intensity was exceptional too, as the anomaly exceeded three standard deviations $\left(t>t_{\mathrm{av}}+3 \sigma\right)$ in Barcelona, Marseilles, Rome, Split, Würzburg, and Vienna, and four standard deviations in Zurich (Table 6). At most of the stations June and/or August were exceptionally hot and at many others the scale of the anomaly exceeded $3 \sigma$. In August, the greatest temperature anomaly was recorded in the south-western part of the Massif Central, France, at Gourdon (Friedrich and Bissolli 2012). In Barcelona and Rome all three summer months were exceptionally hot. The scale of the anomaly ranged from approximately $2^{\circ} \mathrm{C}$ on the Atlantic coast, to $2-3^{\circ} \mathrm{C}$ in Western Europe, to more than $3^{\circ} \mathrm{C}$ in all other locations and it peaked in Zurich at $\Delta t=4.6^{\circ} \mathrm{C}$. In that part of Europe, this was the hottest summer of the study period and at many of the stations also the hottest in the history of measurement (Luterbacher et al. 2004). During that EHS, Western Europe experienced exceptionally hot weather, which caused an unprecedented increase in mortality rates and rapid thawing of Alpine glaciers. Indeed, the scale and intensity of this heat wave was researched in multiple studies (e.g., BUWAL 2004, Fink et al. 2004, Schär et al. 2004, Stott et al. 2004, Chase et al. 2006, D'Ippoliti et al. 2010, Twardosz 2009, Twardosz and Batko 2012). These weather conditions were caused by a highly stable blocking situation over Europe (Fink et al. 2004, Twardosz 2009). A strong high-pressure system centred over Scandinavia with a wedge penetrating into Central Europe dominated the weather, forcing a southern circulation with hot tropical air to stream into Western Europe.

The EHS of 2006 covered 5 stations split between two different areas: northern Spain (La Coruña and Barcelona) and a more central area with Oslo, Copenhagen and Warsaw (Fig. 3). July was exceptionally hot in both areas and their temperature anomalies were similar $\Delta t=1.8-2.4^{\circ} \mathrm{C}$ (Table 6).

The EHS of 2007 covered an area that extended from Debrecen and Belgrade in the west to Rostov on the Don in the east and Istanbul in the south (9 stations) (Fig. 3). The most intensive heat of that summer was recorded in the Balkan Peninsula (Founda and Giannakopoulos 2009). June was exceptionally hot at almost all of the stations, but so was either July or August at some of them. The temperature anomaly ranged from 2.2 to $3.2^{\circ} \mathrm{C}$ (Table 6) 


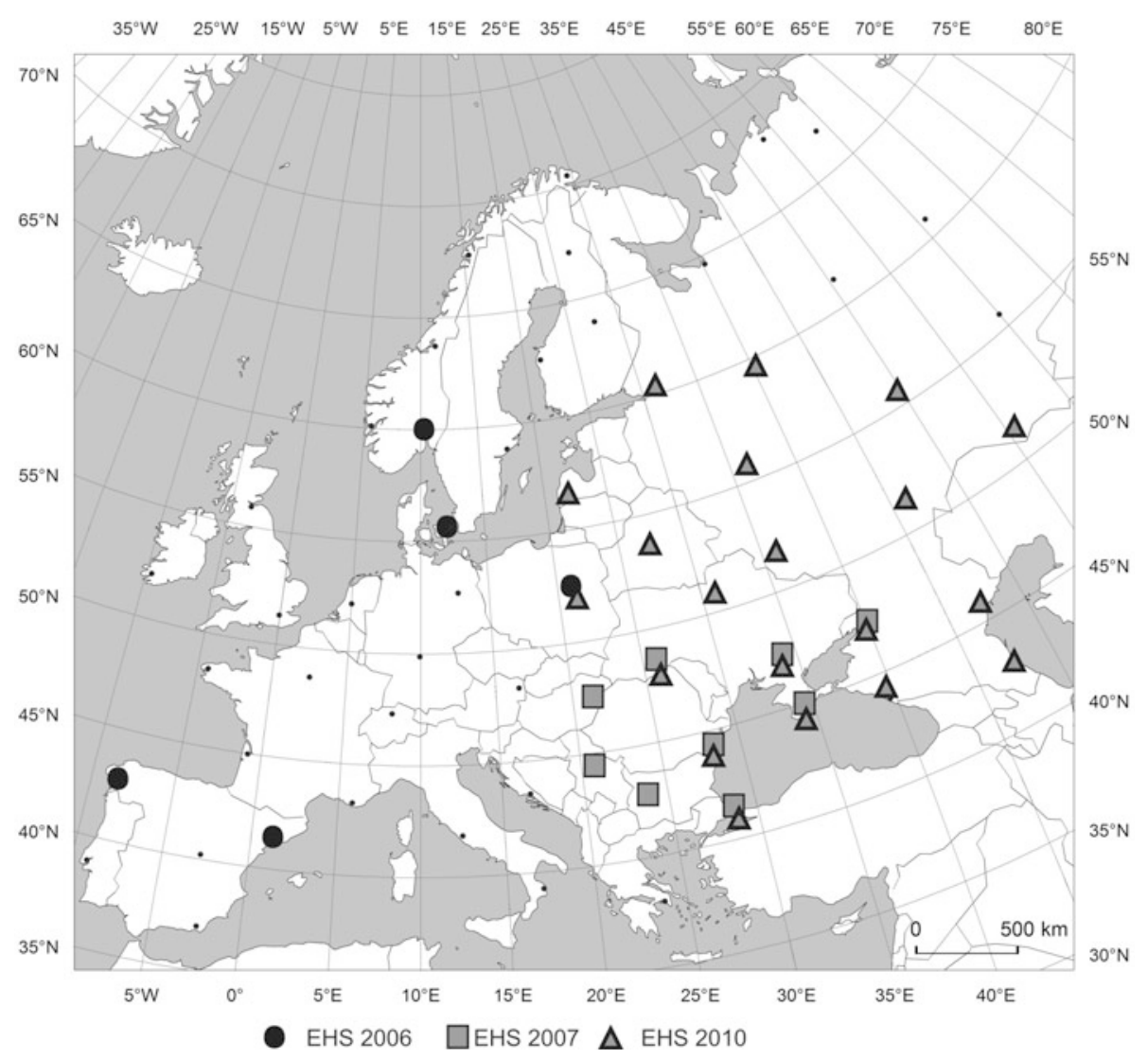

Fig. 3. Stations with EHS: 2006, 2007, and 2010.

without any apparent regularity in their spatial distribution. The highest anomaly was recorded in Simferopol at $\Delta t=3.2^{\circ} \mathrm{C}$.

The EHS of 2010 was the largest in terms of territory, as it involved 20 stations located east of Liepaja and Warsaw and extending all the way to Kazan and Orenburg, and from Istanbul and Makhachkala in the south to St. Petersburg and Vologda in the north (Fig. 3), in other words: Central Europe and European Russia bar its northernmost part. At seven of the 20 stations (in Russia and the Ukraine) the average temperature of the summer exceeded the long-term averages by three or more standard deviations $\left(t \geq t_{\mathrm{av}}+3 \sigma\right)$. In various parts of this extensive area, different months were exceptionally hot and at most of the stations there were two such months (including August almost everywhere), but at Sochi, Astrakhan, Kiev, Kursk, Saratov, Orenburg, Moscow, and Kazan all three months had exceptional temperatures. The temperature anomaly increased from $2.0^{\circ} \mathrm{C}$ at the western limit of the 
area towards the centre of European Russia to reach $5.0^{\circ} \mathrm{C}$ at Kazan, $5.3^{\circ} \mathrm{C}$ at Saratov, and $5.8^{\circ} \mathrm{C}$ at Kursk (Table 6). The EHS of 2010 was therefore not just the largest, but also the most intense. The persistence of a high degree of heat stress caused adverse conditions for human health and negative economic effects, including widespread fires, which, in turn, caused a 2-3 times increase in air pollution over Moscow (Zvyagintsev et al. 2011). Just as in other similar cases in Europe, this exceptionally hot summer had been caused by long-lasting anticyclones (Bardin 2007), the advection of tropical air and long sunshine hours (WMO 2010). A powerful high-pressure bank over Russia created a stable blocking situation that forced southern circulation (Masters 2010, Gruza and Ran'kova 2011).

\section{EXCEPTIONALLY HOT/COOL MONTHS (EHM AND ECM)}

For an exceptionally hot or cool summer to occur there must be a temperature anomaly that is sufficient in scale and duration. For this reason, EHS and (especially) ECS are neither very frequent, nor do they involve large areas in Europe. This is also the reason why there are far more anomalous months (ECM and EHM) than entire summers.

The study has found that there were 119 occurrences of an ECM being recorded during 49 months of the study period. Only 32 of these occurrences (27\%) took place during an ECS, while the remaining 87 were isolated months. June was exceptionally cool 18 times and at 56 stations, in July on 19 times and in 29 stations and August on 12 times and 34 stations. This means that while June and July were equally likely to be exceptionally cool, the June ECM typically covered a far larger area than in July or August.

ECM were most frequently recorded at either one or 2 stations (34 of 49 months, i.e., nearly 70\%) and the two largest ECM covered areas represented by 8 stations (August 1956 coinciding with an ECS at 5 stations in Central Europe) and 7 stations (ECM of June in 1982 in north-western Russia and northern Scandinavia).

ECM were the most frequent in the decade 1971-1980, which included 15 of the 49 ECM and 39 out of 119 occurrences. On both counts, ECM were more numerous than EHM during that decade, even though EHM were much more frequent overall. The lowest number of ECM (7) was recorded in the last of the decades studied, i.e., 2001-2010.

Indeed, EHM were nearly three times as numerous as ECM at 368 occurrences in 83 months of the study period. 144 of these (39\%) were recorded during exceptionally hot summers, which is a much greater percentage than in exceptionally cool summers.

This means that thermally anomalous summers without thermally anomalous months were much more frequent on the cool side than on the hot side 
of the year. Indeed, it was exceedingly rare for two ECM to occur in an ECS (5 occurrences) and there was only one ECS (Almeria in 1977) with all three months exceptionally cool. The picture is the reverse with exceptionally hot summers, which mostly included at least one EHM, quite often two and in the 21st century even all three. Two such seasons with all EHM included the Western-European EHS of 2003 at 2 stations (Barcelona and Rome) and the Eastern-European EHS of 2010 at 5 stations (from Kiev to Astrakhan and Orenburg).

June and July were EHM 26 times each and August 31 times, while the station count increased from June to August with 103, 121, and 144, respectively. The fact that June had $47 \%$ of the ECM occurrences and August had $39 \%$ of the EHM suggests that the gradual warming of the air and ground by solar radiation has an influence on thermal anomalies, even if their fundamental causes are linked with specific types of atmospheric circulation (Kossowska-Cezak 1997).

Just like ECM, EHM also tended to cover areas with one or 2 stations, but significantly less frequently. Only 36 of the 83 (43\%) EHM fell into that category, while the remaining EHS covered much greater territories than ECM. The three largest EHM encompassed 21 stations (August 2003), 20 stations (June 2010), and 17 stations (July 2006 and August 2010). As a comparison, only two ECM covered more than 6 stations (4\%), while 18 EHM (22\%) fitted in that category.

The frequency of EHM over the study period (1951-2010) rose from 38 EHM and 116 occurrences in 1951-1990, to 19 and 69 occurrences in 19912000 , and to 26 and 183 occurrences in 2001-2010. This means that the last decade of the study accounts for one half of all EHM occurrences and the last two decades account for $69 \%$ of such occurrences. It must be added that during the last 20 years, and more precisely from 1987, an EHM was recorded somewhere in Europe every year. The rapid increase in EHM occurrence in the 21 st century is linked with the fact that they are not only more frequent, but also cover ever greater territories. Another phenomenon of the 21 st century worthy of note is the unprecedented scale of thermal anomalies during EHM and EHS, which exceed three or even four standard deviations.

There is also an interesting category of summers with a "both-way anomaly", when an EHM in one part of Europe coincides with an ECM in another. There were 16 such months when some of the 49 ECM and 83 EHM overlapped in a single month. Examples include June and August 1972: a June ECM was recorded at 6 stations in the far west of Europe, while an EHM occurred at the 2 discrete stations of Bodo and Rostov; in August there was an ECM in Barcelona, while 11 Russian stations recorded an EHM. In 1991, June was an ECM at 5 stations on the North Sea coast and in southern Scandinavia, but it was also an EHM at 4 stations in the far east 
of Europe. 2003 was a reverse of that situation, as Western Europe experienced its hottest and largest June EHM (11 stations), while at the same time 4 Russian stations recorded an ECM.

\section{CONCLUSIONS}

The study used a relatively precise statistical criterion $\left(t \leq t_{\mathrm{av}}-2 \sigma\right.$ or $t \geq t_{\mathrm{av}}+2 \sigma$ ) to identify exceptionally hot and cool summers (EHS and ECS) during the 60-year study period from 1951 to 2010 at 60 European weather stations. Alongside the entire summer seasons the study also looked at exceptional months.

It was found that EHS were approximately twice as frequent as ECS and occurred virtually in the whole study area, while the ECS were concentrated in its northern part. ECS were observed in 13 years, while EHS in 24 years, but a half of both types of exceptional summer were only recorded at 1 or 2 stations (6 and 14, respectively). Such thermally anomalous summers rarely covered large areas, as only three ECS $(1956,1962$, and 1976) and five EHS $(1972,2002,2003,2007$, and 2010) were recorded by at least $10 \%$ of the stations.

EHS were not just more frequent than ECS and likely to occur anywhere in Europe, but also their extreme occurrences covered much larger territories with up to one quarter or even one third of all stations included in the study. What is more, the extreme occurrences of EHS featured higher temperature anomalies than the respective ECS (in excess of $5.0^{\circ} \mathrm{C}$ compared to less than $4.0^{\circ} \mathrm{C}$ in the case of the most extreme ECS).

The greater frequency, greater territorial coverage and the extreme scale of the thermal anomalies of both EHM and EHS, when compared to ECM and ECS, suggests a potential for prolonged periods of radically increased air temperatures in Europe during the summer season, i.e., at a time of maximum sunshine duration. This increase is also linked with the advection of hot tropical or continental air. On the other hand, an influx of much cooler arctic or polar maritime air is sufficiently offset by the sunshine potential on long summer days to prevent an equivalent drop of air temperature.

The frequencies of EHS and ECS varied over the study period. The most distinctive feature of this variability was the gradual disappearance of ECS and the simultaneous increase in the frequency of EHS beginning in the mid1990s. The latter not only grew in frequency, but also in size and severity, as the most extensive and the hottest EHS occurred in the 21st century, namely in 2003 in Western Europe and in 2010 in Eastern Europe.

The results of this study are of a preliminary nature and the authors intend to embark on a comprehensive study involving all four seasons with 
anomalous temperatures in Europe using data from a much greater pool of stations.

Acknowledgements. We thank Mr. Paweł Pilch and Dr. Martin Cahn for reviewing the English.

\section{References}

Anisimov, O.A., I.I. Borzenkova, E.L. Zhil'tsova, O.K. Zakharova, V.A. Kokorev, S.A. Reneva, and Yu.G. Strel'chenko (2011), Hydrometeorological conditions of the Volga region and current climate changes, Rus. Meteorol. Hydrol. 36, 5, 307-314, DOI: 10.3103/S1068373911050049.

BUWAL (2004), Auswirkungen des Hitzesommers 2003 auf die Gewässer. Dokumentation, Schriftenreiche Umwelt, Nr. 369, Gewässerschutz, Bundesamt für Umwelt, Wald und Landschaft, Bern (in German).

Bardin, M.Yu. (2007), Anticyclonic quasi-stationary circulation and its effect on air temperature anomalies and extremes over western Russia, Rus. Meteorol. Hydrol. 32, 2, 75-84, DOI: 10.3103/S106837390702001X.

Bardin, M.Yu. (2011), Scenary forecasts of air temperature variations for the regions of the Russian Federation up to 2030 using the empirical stochastic climate models, Rus. Meteorol. Hydrol. 36, 4, 217-228, DOI: 10.3103/ S1068373911040017.

Barriopedro, D., E.M. Fischer, J. Luterbacher, R.M. Trigo, R. García-Herrera (2011), The hot summer of 2010: Redrawing the temperature record map of Europe, Science 332, 6026, 220-224, DOI: 10.1126/science.1201224.

Black, E., and R. Sutton (2007), The influence of oceanic conditions on the hot European summer of 2003, Clim. Dyn. 28, 1, 53-66, DOI: 10.1007/s00382006-0179-8.

Błażejczyk, K., and G. McGregor (2007), Bio-thermal conditions and mortality in selected European agglomerations, Prz. Geogr. 79, 3-4, 627-649 (in Polish).

Chase, T.N., K. Wolter, R.A. Pielke Sr., and I. Rasool (2006), Was the 2003 European summer heat wave unusual in a global context?, Geophys. Res. Lett. 33, 23, L23709, DOI: 10.1029/2006GL027470.

Coumou, D., A. Robinson, and S. Rahmstorf (2013), Global increase in recordbreaking monthly-mean temperatures, Climatic Change 118, 3-4, 771-782, DOI: $10.1007 / \mathrm{s} 10584-012-0668-1$.

de Freitas, C.R. (2003), Tourism climatology: evaluating environmental information for decision making and business planning in the recreation and tourism sector, Int. J. Biometeorol. 48, 1, 45-54, DOI: 10.1007/s00484-003-0177-z.

Della-Marta, P.M., J. Luterbacher, H. von Weissenfluh, E. Xoplaki, M. Brunet, and H. Wanner (2007), Summer heat waves over western Europe 1880-2003, 
their relationship to large-scale forcings and predictability, Clim. Dyn. 29, 2-3, 251-275, DOI: 10.1007/s00382-007-0233-1.

D’Ippoliti, D., P. Michelozzi, C. Marino, F. de'Donato, B. Menne, K. Katsouyanni, U. Kirchmayer, A. Analitis, M. Medina-Ramón, A. Paldy, R. Atkinson, S. Kovats, L. Bisanti, A. Schneider, A. Lefranc, C. Iñiguez, and C.A. Perucci (2010), The impact of heat waves on mortality in 9 European cities: results from the EuroHEAT project, Environ. Health 9, 37, 1-9, DOI: 10.1186/1476-069X-9-37.

Dole, R., M. Hoerling, J. Perlwitz, J. Eischeid, P. Pegion, T. Zhang, X.W. Quan, T. Xu, and D. Murray (2011), Was there a basis for anticipating the 2010 Russian heat wave?, Geophys. Res. Lett. 38, 6, L06702, DOI: 10.1029/ 2010GL046582.

Donat, M.G., L.V. Alexander, H. Yang, I. Durre, R. Vose, R.J.H. Dunn, K.M. Willett, E. Aguilar, M. Brunet, J. Caesar, B. Hewitson, C. Jack, A.M.G. Klein Tank, A.C. Kruger, J. Marengo, T.C. Peterson, M. Renom, C. Oria Rojas, M. Rusticucci, J. Salinger, A.S. Elrayah, S.S. Sekele, A.K. Srivastava, B. Trewin, C. Villarroel, L.A. Vincent, P. Zhai, X. Zhang, and S. Kitching (2013), Updated analyses of temperature and precipitation extreme indices since the beginning of the twentieth century: The HadEX2 dataset, J. Geophys. Res. 118, 5, 2098-2118, DOI: 10.1002/jgrd.50150.

Elizbarashvili, E.Sh., R.Sh. Meskhiya, and M.E. Elizbarashvili (2007), Dynamics of occurrence frequency of extreme anomalies of monthly mean air temperature in Georgia in the 20th century and its effect on precipitation and on the river water discharge, Rus. Meteorol. Hydrol. 32, 1, 71-74, DOI: $10.3103 / \mathrm{S} 1068373907010116$.

Feudale, L., and J. Shukla (2011), Influence of sea surface temperature on the European heat wave of 2003 summer. Part I: an observational study, Clim. Dyn. 36, 9-10, 1691-1703, DOI: 10.1007/s00382-010-0788-0.

Filipiuk, E., and B.M. Kaszewski (2000), Hot and cold summers in Central Europe (1871-1990), Prace Geogr. 108, 149-154.

Fink, A.H., T. Brücher, A. Krüger, G.C. Leckebusch, J.G. Pinto, and U. Ulbrich (2004), The 2003 European summer heatwaves and drought - synoptic diagnosis and impacts, Weather 59, 8, 209-216, DOI: 10.1256/wea.73.04.

Fischer, E.M., and C. Schär (2010), Consistent geographical patterns of changes in high-impact European heatwaves, Nat. Geosci. 3, 398-403, DOI: 10.1038/ ngeo866.

Founda, D., and C. Giannakopoulos (2009), The exceptionally hot summer of 2007 in Athens, Greece - A typical summer in the future climate?, Global Planet. Change 67, 3-4, 227-236, DOI: 10.1016/j.gloplacha.2009.03.013.

Friedrich, K., and P. Bissolli (2012), Analysis of temperatures and precipitation recorded at stations in Eastern Europe during the heat wave in summer 2010, Deutscher Wetterdienst, Business Area Climate and Environment, http://www.dwd.de/bvbw/generator/DWDWWW/Content/Oeffentlichkeit/ 
KU/KU2/KU23/rcc-cm/products/BesondereWetterereignisse/European/ 20110124 Hitzewelle_Russland_de,templateId=raw,property=publicati onFile.pdf/20110124_Hitzewelle_Russland_de.pdf.

Gerstengarbe, F.W., and P.C. Werner (1992), The time structure of extreme summers in Central Europe between 1901 and 1980, Meteorol. Z. 1, 6, 285-289.

Gruza, G.V., and E.Ya. Ran'kova (2011), Estimation of probable contribution of global warming to the genesis of abnormally hot summers in the European part of Russia, Izv. Atmos. Ocean. Phys. 47, 6, 661-664, DOI: 10.1134/ S0001433811060065.

Hansen, J., M. Sato, and R. Ruedy (2012), Perception of climate change, Proc. Natl. Acad. Sci. U.S.A. 109, 37, E2415-E2423, DOI: 10.1073/pnas.1205276109.

Hodzic, A., S. Madronich, B. Bohn, S. Massie, L. Menut, and C. Wiedinmyer (2007), Wildfire particulate matter in Europe during summer 2003: mesoscale modeling of smoke emissions, transport and radiative effects, Atmos. Chem. Phys. 7, 15, 4043-4064.

Hutter, H.P., H. Moshammer, P. Wallner, B. Leitner, and M. Kundi (2007), Heatwaves in Vienna: effects on mortality, Wien. Klin. Wochenschr. 119, 7-8, 223-227, DOI: 10.1007/s00508-006-0742-7.

IPCC (2013), Summary for policymakers. In: T.F. Stocker, D. Qin, G.-K. Plattner, M. Tignor, S.K. Allen, J. Boschung, A. Nauels, Y. Xia, V. Bex, and P.M. Midgley (eds.), Climate Change 2013: The Physical Science Basis. Working Group I. Contribution to the Fifth Assessment Report of the Intergovernmental Panel on Climate Change, Cambridge University Press, Cambridge, 3-32.

Isayev, A.A., and B.G. Sherstyukov (2008), Mean and extreme characteristics of Moscow climate at the end of the 20th century, Rus. Meteorol. Hydrol. 33, 3, 151-158, DOI: 10.3103/S1068373908030035.

Jaagus, J. (2006), Climatic changes in Estonia during the second half of the 20th century in relationship with changes in large-scale atmospheric circulation, Theor. Appl. Climatol. 83, 1-4, 77-88, DOI: 10.1007/s00704-005-0161-0.

Jones, G.S., P.A. Stott, and N. Christidis (2008), Human contribution to rapidly increasing frequency of very warm Northern Hemisphere summers, J. Geophys. Res. 113, D2, D02109, DOI: 10.1029/2007JD008914.

Jones, P.D., D.H. Lister, T.J. Osborn, C. Harpham, M. Salmon, and C.P. Morice (2012), Hemispheric and large-scale land-surface air temperature variations: An extensive revision and an update to 2010, J. Geophys. Res. 117, D5, D05127, DOI: 10.1029/2011JD017139.

Kamae, Y., H. Shiogama, M. Watanabe, and M. Kimoto (2014), Attributing the increase in Northern Hemisphere hot summers since the late 20th century, Geophys. Res. Lett. 41, 14, 5192-5199, DOI: 10.1002/2014GL061062.

Klein Tank, A.M.G., J.B. Wijngaard, G.P. Können, R. Böhm, G. Demarée, A. Gocheva, M. Mileta, S. Pashiardis, L. Hejkrlik, C. Kern-Hansen, R. Heino, P. Bessemoulin, G. Müller-Westermeier, M. Tzanakou, S. Szalai, 
T. Pálsdóttir, D. Fitzgerald, S. Rubin, M. Capaldo, M. Maugeri, A. Leitass, A. Bukantis, R. Aberfeld, A.F.V. van Engelen, E. Forland, M. Mietus, F. Coelho, C. Mares, V. Razuvaev, E. Nieplova, T. Cegnar, J. Antonio López, B. Dahlström, A. Moberg, W. Kirchhofer, A. Ceylan, O. Pachaliuk, L.V. Alexander, and P. Petrovic (2002), Daily dataset of 20th-century surface air temperature and precipitation series for the European Climate Assessment, Int. J. Climatol. 22, 12, 1441-1453, DOI: 10.1002/joc.773.

Kossowska-Cezak, U. (1993), Summer 1992 in Poland against summer seasons of 120-years period, Prz. Geofiz. 38, 1, 67-74 (in Polish).

Kossowska-Cezak, U. (1997), Monthly thermal and precipitation conditions and their dependence on atmospheric circulation, Prace Stud. Geograf. 20, 125144 (in Polish).

Kossowska-Cezak, U. (2010), Occurrence of hot weather in Warsaw (1951-2009), Prz. Geofiz. 2010, 1-2, 61-75 (in Polish).

Kossowska-Cezak, U., and R. Twardosz (2012a), Exceptionally hot summer months and seasons in Central and Eastern Europe (1951-2010). Part I. Exceptionally hot summer months, Prz. Geofiz. 2012, 3-4, 299-324 (in Polish).

Kossowska-Cezak, U., and R. Twardosz (2012b), Exceptionally hot summer months and seasons in Central and Eastern Europe (1951-2010). Part II. Exceptionally hot summer seasons, Prz. Geofiz. 2012, 3-4, 325-342 (in Polish).

Kossowska-Cezak, U., and R. Twardosz (2013), Exceptionally cool summers in Central and Eastern Europe (1951-2010), Prz. Geofiz. 2013, 1-2, 25-39 (in Polish).

Krzyżewska, A., and S. Wereski (2011), Heat waves and frost waves in selected Polish stations against bioclimatic regions background (2000-2010), Prz. Geofiz. 2011, 1-2, 99-109 (in Polish).

Kürbis, K., M. Mudelsee, G. Tetzlaff, and R. Brázdil (2009), Trends in extremes of temperature, dew point, and precipitation from long instrumental series from central Europe, Theor Appl. Climatol. 98, 1-2, 187-195, DOI: 10.1007/s00704-008-0094-5.

Kuziemska, D. (1975), Atmospheric precipitation in cool, temperate and warm months of the year in Warsaw, Temat 1.05.04, Problem 157, Institute of Meteorology and Water Management (IMGW), Warszawa, Poland, 1-28 (in Polish).

Kuziemska, D. (1987), The air temperature differentiation on Poland area and atmospheric circulation types over central Europe, Prz. Geofiz. 3, 277-287 (in Polish).

Kyselý, J. (2010), Recent severe heat waves in central Europe: how to view them in a long-term prospect?, Int. J. Climatol. 30, 1, 89-109, DOI: 10.1002/ joc. 1874 .

Kyselý, J., and R. Huth (2008), Relationships of surface air temperature anomalies over Europe to persistence of atmospheric circulation patterns conducive to heat waves, Adv. Geosci. 14, 243-249, DOI: 10.5194/adgeo-14-243-2008. 
Luterbacher, J., D. Dietrich, E. Xoplaki, M. Grosjean, and H. Wanner (2004), European seasonal and annual temperature variability, trends, and extremes since 1500, Science 303, 5663, 1499-1503, DOI: 10.1126/science.1093877.

Masters, J. (2010), Causes of the Russian heat wave and Pakistani floods, Dr. Jeff Master's WunderBlog, http://www.wunderground.com/blog/JeffMasters/ comment.html? entrynum=1576 (retrieved on 9 February 2011).

Meehl, G.A., and C. Tebaldi (2004), More intense, more frequent, and longer lasting heat waves in the 21 st century, Science 305, 5686, 994-997, DOI: 10.1126 / science. 1098704.

Moberg, A., P.D. Jones, D. Lister, A. Walther, M. Brunet, J. Jacobeit, L.V. Alexander, P.M. Della-Marta, J. Luterbacher, P. Yiou, D. Chen, A.M.G. Klein Tank, O. Saladié, J. Sigró, E. Aguilar, H. Alexandersson, C. Almarza, I. Auer, M. Barriendos, M. Begert, H. Bergström, R. Böhm, C. J. Butler, J. Caesar, A. Drebs, D. Founda, F.-W. Gerstengarbe, G. Micela, M. Maugeri, H. Österle, K. Pandzic, M. Petrakis, L. Srnec, R. Tolasz, H. Tuomenvirta, P.C. Werner, H. Linderholm, A. Philipp, H. Wanner, and E. Xoplaki (2006), Indices for daily temperature and precipitation extremes in Europe analyzed for the period 1901-2000, J. Geophys. Res. 111, D22, D22106, DOI: 10.1029/2006JD007103.

Muthers, S., A. Matzarakis, and E. Koch (2010), Climate change and mortality in Vienna - A human biometeorological analysis based on regional climate modeling, Int. J. Environ. Res. Public Health 7, 7, 2965-2977, DOI: 10.3390/ijerph7072965.

Perkins, S.E., L.V. Alexander, and J.R. Nairn (2012), Increasing frequency, intensity and duration of observed global heatwaves and warm spells, Geophys. Res. Lett. 39, 20, L20714, DOI: 10.1029/2012GL053361.

Piervitali, E., M. Conte, and M. Colacino (1997), Summer air temperature anomalies in Europe during the century 1811-1910, Nuovo Cimento C 20, 2, 195-208.

Rebetez, M., O. Dupont, and M. Giroud (2009), An analysis of the July 2006 heatwave extent in Europe compared to the record year of 2003, Theor. Appl. Climatol. 95, 1-2, 1-7, DOI: 10.1007/s00704-007-0370-9.

Révész, A. (2008), Stochastic behaviour of heat waves and temperature in Hungary, Appl. Ecol. Environ. Res. 6, 4, 85-100, DOI: 10.15666/aeer/0604_085100.

Revich, B.A., and D.A. Shaposhnikov (2012), Climate change, heat waves, and cold spells as risk factors for increased mortality in some regions of Russia, Stud. Rus. Econom. Develop. 23, 2, 195-207, DOI: 10.1134/ S1075700712020116.

Schär, C., P.L. Vidale, D. Lüthi, C. Frei, C. Häberli, M.A. Liniger, and C. Appenzeller (2004), The role of increasing temperature variability in European summer heatwaves, Nature 427, 6972, 332-336, DOI: 10.1038/nature 02300 .

Scott, D., and C. Lemieux (2010), Weather and climate information for tourism, Procedia Environ. Sci. 1, 146-183, DOI: 10.1016/j.proenv.2010.09.011. 
Sidorenkov, N.S., and I.A. Orlov (2008), Atmospheric circulation epochs and climate changes, Rus. Meteorol. Hydrol. 33, 9, 553-559, DOI: 10.3103/ S1068373908090021.

Sillmann, J., V.V. Kharin, X. Zhang, F.W. Zwiers, and D. Bronaugh (2013), Climate extremes indices in the CMIP5 multimodel ensemble: Part 1. Model evaluation in the present climate, J. Geophys. Res. 118, 4, 1716-1733, DOI: 10.1002/jgrd.50203.

Sillmann, J., M.G. Donat, J.C. Fyfe, and F.W. Zwiers (2014), Observed and simulated temperature extremes during the recent warming hiatus, Environ. Res. Lett. 9, 6, 064023, DOI: 10.1088/1748-9326/9/6/064023.

Stott, P.A., D.A. Stone, and M.R. Allen (2004), Human contribution to the European heatwave of 2003, Nature 432, 7017, 610-614, DOI: 10.1038/nature03089.

Trigo, R.M., J.M. Vaquero, M.J. Alcoforado, M. Barriendos, J. Taborda, R. GarcíaHerrera, and J. Luterbacher (2009), Iberia in 1816, the year without a summer, Int. J. Climatol. 29, 1, 99-115, DOI: 10.1002/joc.1693.

Twardosz, R. (2009), Extraordinary heat waves in 21st century Europe, Prz. Geofiz. 2009, 3-4, 193-204 (in Polish).

Twardosz, R., and A. Batko (2012), Heat waves in Central Europe (1991-2006), Int. J. Global Warm. 4, 3-4, 261-272, DOI: 10.1504/IJGW.2012.049430.

Twardosz, R., and U. Kossowska-Cezak (2013a), Exceptionally hot summers in Central and Eastern Europe (1951-2010), Theor. Appl. Climatol. 112, 3-4, 617-628, DOI: 10.1007/s00704-012-0757-0.

Twardosz, R., and U. Kossowska-Cezak (2013b), Exceptionally hot summers months in Central and Eastern Europe during the years 1951-2010. In: I. Dincer, C. Ozgur Colpan, and F. Kadioglu (eds.), Causes, Impacts and Solutions to Global Warming, Springer, New York, 17-35, DOI: 10.1007/ 978-1-4614-7588-0_2.

Twardosz, R., and U. Kossowska-Cezak (2013c), Exceptional thermal anomalies in the Atlantic-European area of the sub-polar zone, Probl. Klimatol. Polar. 23, 93-105 (in Polish).

Twardosz, R., E. Łupikasza, and T. Niedźwiedź (2011), Temporal Variability in the Form and Type of Precipitation in Kraków in Relation to Circulation Patterns, Wydawnictwo UJ, Kraków, 174 pp. (in Polish).

Unal, Y.S., E. Tan, and S.S. Mentes (2013), Summer heat waves over western Turkey between 1965 and 2006, Theor. Appl. Climatol. 112, 1-2, 339-350, DOI: $10.1007 / \mathrm{s} 00704-012-0704-0$.

Wehry, W. (2010), Der heisse Sommer 2010 in Russland - Teil 2: Meteorologische Ursachen der Waldbrände, Beitr. Berliner Wetterkarte 52/10 (SO 24/10) (in German).

Wijngaard, J.B., A.M.G. Klein Tank, and G.P. Können (2003), Homogeneity of 20th century European daily temperature and precipitation series, Int. J. Climatol. 23, 6, 679-692, DOI: 10.1002/joc.906. 
WMO (2010), Extreme weather events, World Meteorological Organization, http://www.wmo.int/pages/mediacentre/news/extremeweathersequence_en. html (retrieved on 9 February 2011).

Zveryaev, I., Yu. Zyulyaeva, S. Gulev, and P. Koltermann (2012), Intercomparison of the Russian summer heatwaves of 2010 and 1972. In: EGU General Assembly, 22-27 April 2012, Vienna, Austria, EGU2012-9714.

Zvyagintsev, A.M., O.B. Blum, A.A. Glazkova, S.N. Kotel'nikov, I.N. Kuznetsova, V.A. Lapchenko, E.A. Lezina, E.A. Miller, V.A. Milyaev, A.P. Popikov, E.G. Semutnikova, O.A. Tarasova, and I.Yu. Shalygina (2011), Air pollution over European Russia and Ukraine under the hot summer conditions of 2010, Izv., Atmos. Ocean. Phys. 47, 6, 699-707, DOI: 10.1134/ S0001433811060168.

Received 19 August 2014 Received in revised form 5 November 2014

Accepted 18 November 2014 